\title{
Prayer and being church in postapartheid, multicultural South Africa
}

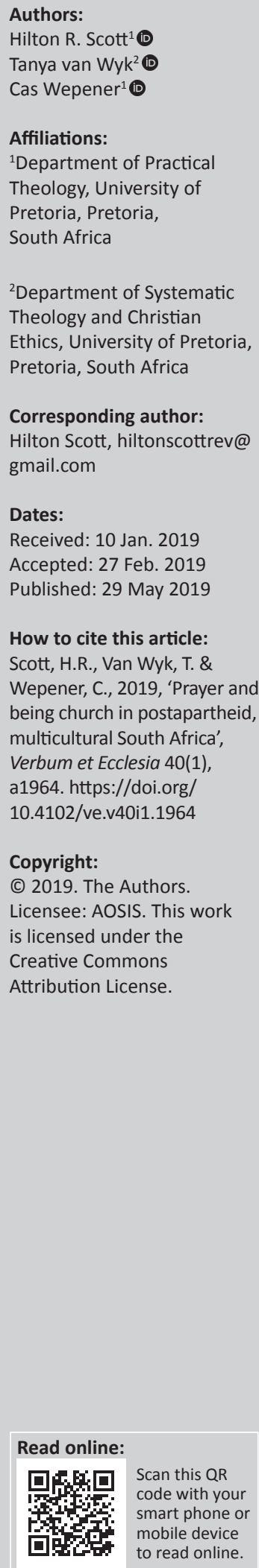

The research presented in this article was conducted as a continuing concern over 'being church' in a multicultural urban setting in postapartheid South Africa. It has been nearly 30 years since the end of apartheid and South Africans are still learning to live together in unity, as the pioneers of democracy envisaged. In this contribution, it is suggested that in this context, prayer could be utilised as an instrument for church-praxis. This is done by taking an interdisciplinary approach, namely, integrating theories from the fields of practical theology and systematic theology with regard to liturgical studies and ecclesiology, and using them to interpret empirical data and to build on the process of liturgical inculturation. The concept of 'koinonia' is explored by reflecting on the relationship between inclusivity and exclusivity and integrating it with contemporary praxis theory from liturgical studies. This is aimed at promoting a manner of 'being church' that reflects Dirk Smit's aphorism, of lex orandi, lex credendi, lex (con)vivendi, that is, as we pray, so we believe, and so we live (together).

Intradisciplinary and/or interdisciplinary implications: The research presented in this article was conducted as a continuing concern over 'being church' in a multicultural, urban setting in postapartheid South Africa. This is done by taking an interdisciplinary approach, integrating theories from the fields of practical theology and systematic theology with regard to liturgical studies and ecclesiology.

Keywords: liturgical inculturation; inclusivity; exclusivity; being church; prayer; liturgical rituals.

\section{Introduction}

The Republic of South Africa displays a diversity of cultures, languages and individuals in relation with one another. South Africans, as a nation, are still learning to live together in unity

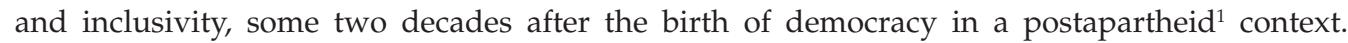
This context cannot be overlooked, neither can the multicultural context of urban South Africa, as it is mirrored in some church communities. The working hypothesis for the results of the investigation presented in this article is, as people live together and with one another, they think and talk together and with one another, and so they believe together and with one another, and so this 'togetherness-in-diversity' is reflected in their prayer. Can the church, by way of liturgy and prayer, make a meaningful contribution to cohesion in South Africa, in terms of how people connect to one another? How could this happen? It is argued here that it could take place by way of a specific form of liturgical inculturation, which takes into serious account the relationship between the praxis of prayer and ecclesiology. Prayer affects belief, which affects being church, while belief affects prayer and being church, furthermore while being church affects prayer and belief.

Prayer, as a liturgical ritual, is a form of communication (Barnard, Cilliers \& Wepener 2014:362; Grimes 2010:43; Scott 2018:4, 166; VandeCreek et al. 2002:30; Wepener 2009:21). Communication is a lot more than simply the way one talks to another; it is also about the language one uses; the emotion behind certain terms, for example, terms of endearment; the topics that are discussed; the questions that are asked; and the requests that are made. One will notice aspects of respect, love, honour and humility, as well as the opposite end of the spectrum: disrespect, anger, shame and pride. Furthermore, people have the ability to communicate with their body language, bodily gestures, clothing and the style and colours of clothing items as well as that which is displayed either graphically or in written words thereon (Scott 2018:2; Wepener 2006:387). Prayer is a form of communication between fellow believers and paramountly between believer(s) and God. 1.The term "postapartheid" is deliberately used in this manner, in other words without a hyphen between "post' and 'apartheid", to
emphasise the reality that the ideology is unfortunately not truly in the past. The use of a hyphen would signify that apartheid is well and truly 'post-' or behind, which is not the lived reality as is evident by ongoing transformation in South Africa. 
Prayer forms a massive part of the liturgy in a worship service and the church is known as a 'hospital for sinners not a museum for saints', a hospital that should be overflowing owing to the nature of the world and all its problems (cf. Scott \& Wepener 2017; Wepener 2012). Hospitals are places of healing, and healing is something that can be achieved through therapy.

Prayer also, thus, has a therapeutic dimension (cf. Lukken 1999). Therapy comes in many different forms and has many different elements (Scott 2013:3-4). As an example, therapy can come in the form of a ritual within the worship service, and the efficacy of such a ritual could depend on the inclusivity, unity and 'being church' that a worshipper experiences in the worship service. With the aim of healing through inclusivity and unity - being church (cf. Ackermann 1998; Van Deusen Hunsinger 2009:348; Van Wyk 2014; Volf 1996; Zizioulas 2006) - a theory for praxis will be suggested that includes the therapeutic dimensions of prayer in terms of connectedness.

Being church pertains to living (together) through faith and worship (or prayer) as is depicted by Smit's (2004) aphoristic notion of lex orandi, lex credendi, lex (con)vivendi. Thus, there is concern over how the liturgical form and content of prayer affect 'being church' in urban South Africa, owing to the understanding that: 'as we pray, so we believe, and so we live (together)' (Scott 2018:1). In other words, there are causal interrelationships between prayer, belief and being church. This article takes an interdisciplinary approach to promoting 'being church' in a multicultural, pluralistic, postapartheid South Africa by building on the process of liturgical inculturation.

The following is an explanation of these causal interrelationships: as people worship (or pray), so should they believe, think and talk and as they believe, think and talk, so should they live - each and everyone together (Smith 2004:890). In a similar regard: as people live together and with one another, so should they believe, think and talk and as they believe, think and talk, so should they pray. Prayer affects belief, which affects being church, while belief affects prayer and being church, furthermore while being church affects prayer and belief. Thus, by using prayer as an instrument, being church in a multicultural urban setting in postapartheid South Africa should be affected through the ongoing process of liturgical inculturation (See Chupungco 1992).

\section{Methodology}

In his book, Practical theology: An introduction, Osmer (2008) discusses four tasks of practical theological interpretation. The questions of importance are: 'what is going on?', which is presented by the descriptive-empirical task, and 'what ought to be going on?' which is a question associated with the normative task. The former of these tasks aims at gathering information that helps discern patterns and dynamics in particular episodes, situations and contexts (Osmer 2008:4,
31-78), in relation to the research question that is concerned with how the liturgical form and content of prayer impacts 'being church' in a multicultural pluralistic, postapartheid South Africa. The question 'what is going on?' is answered by making use of various qualitative research techniques that allowed the researcher, through carefully constructed methodology, to gather empirical data on prayer as a liturgical ritual. Such an approach of conducting qualitative research has become the 'tradition' of Liturgical Studies researchers (cf. Barnard et al. 2014:11-49; Johnson 2005; Lloyd, Steven \& Tovey 2010; Post 2015; Scott \& Wepener 2017; Wepener 2005, 2009:23-32, 2015; Wepener \& Barnard 2010).

The so-called normative task, focusses on drawing on theological concepts to interpret episodes, situations and contexts - illuminated by the descriptive-empirical task - to construct ethical norms. This aids in developing a theory for praxis while learning from 'good practice' (cf. Osmer 2008:4; Scott 2018:168; Smith 2010:107-108). In this case, a new interdisciplinary relationship is formed between Liturgical Studies and Systematic Theological Ecclesiology, which led to - through the formation of new knowledge - a more comprehensive theory for praxis. From an interdisciplinary, and a multidisciplinary, perspective, the fields of Ritual Studies and Liturgical Studies have been integrated before. The relationship between these two fields should not be new to scholars and researchers in the field of Liturgical Studies. Barnard et al. (2014) - for example - consider a field of 'Liturgical ritual studies' while Grimes (2010:44) sees liturgy as one of the 'fundamental impulses of ritual' and acknowledges liturgy as a mode of ritual (Grimes 2010:47; Post 2015). Understanding that there is already a relationship between Liturgical Studies and Ritual Studies, scholars can take an interdisciplinary approach which results in new knowledge emerging by integrating theories from allied fields (Scott 2018:21-23). However, this relationship is not unique and has been explored before (cf. De Klerk 2016:6; Flynn 2015; Scott 2013, 2018; Scott \& Wepener 2017; Wepener $2005,2009)$. In the proceeding sections, the interdisciplinary relationship between theory from Liturgical Studies and Systematic Theological Ecclesiology will be explored in detail, as it aids the development of a theory for praxis that is concerned with 'being church' in a multicultural, urban South Africa. ${ }^{2}$

In the section below, the background and theory will be presented in such a fashion that the theory from Liturgical Studies and Systematic Theological Ecclesiology are separate fields. The reason for this is to show how, through interdisciplinarity, theories began being integrated to form new knowledge that led to a new theory for praxis. An interdisciplinarity approach is carried throughout the research project; for this reason, the background of the

2.Another unique aspect of this research project was that empirical data were collected across the broad ritual landscape of prayer and not only as a practice collected across the broad ritual landscape of prayer and not only as a practice within the worship service. Secondly, the empirical data were collected on the form(s) of prayer as a liturgical ritual - not only the content of prayer. The latter was conducted owing to the understanding that the form and content of prayer, as a ritual, are interconnected (cf. Grimes 2010:35; Scott 2018:150; Wepener 2009:36) However, the aim of this article is to explore the relationship between Liturgica Studies and Systematic Theological Ecclesiology as a result of a concern over liturgical inculturation, inclusivity and exclusivity in a pluralistic setting. 
research project will be intertwined with the theory below. This is to illuminate the process and illustrate the field and empirical research process.

\section{Background and theory}

This section has been divided into three clear subsections, namely, Culture and multiplicity, The liturgical approach and The ecclesiological approach. The first subsection describes how culture is understood for the purposes of the research project. The second subsection describes and discusses theory around liturgical approaches to integrating culture(s). The last subsection, which focusses on 'inclusivity', discusses ecclesiological theory from a systematic theology perspective.

\section{Culture and multiplicity}

The importance of understanding the term culture in relation to the context lies in the identification of this metropolitan setting being multicultural. The definitions, or explanations, used to understand such terms as liturgical inculturation discuss culture and its relationship to the liturgy - in what appears to be - the singular. Thus, the term 'culture' in this context denotes, first and foremost, the existence of multiple cultures. As a starting point, culture is understood as that which forms part of one's heritage and not popular culture (or pop culture)' (Scott 2018:14). It is also understood that culture, in a South African sense, is directly related to one's home language or mother tongue (Scott 2018:6). As in, a person with a Zulu cultural background should, at least as it has been observed, claim that isiZulu is his or her mother tongue - or that they at least speak the language. Similarly to one's mother tongue, culture is normally inherited or passed on from one generation to the next. This system of inheriting and passing on from one generation to the next can be progressive as one 'writes' one's own story from the 'cultural story' one has inherited (Bosman \& Müller 2009:1). This depicts a scene where, not only is a person part of a culture but culture is part of them. Therefore, 'culture' can also be seen as a factor that contributes to a complex web - or matrix - that defines an individual (cf. Scott 2018:28, 174, $175,186)$. This is an aspect which will be discussed further below when considering Systematic Theological perspectives on inclusivity and exclusivity. 'Culture' is understood as 'describing the complex aspects that culminate to determine someone's context and the way in which one experiences the worship service' (Scott 2018:28).

Before considering the approaches from the fields of Liturgical Studies and Systematic Theology, more background should be given. Culture, as it is understood for the research project, has been discussed above. The reason for focussing on culture throughout the research process is based on an aphorism developed by Dirk Smit (2004): Lex orandi, lex credendi, lex (con)vivendi. Loosely translated, it suggests that: 'as we pray, so we believe, so we live (together)' (Scott 2018). Consider the following excerpt, which provides context:

This presupposes a causal interrelationship between prayer, belief and being church. As an explanation of this causal interrelationship, consider the following: as people worship (or pray), so should they believe, think and talk and as they believe, think and talk, so should they live - each and everyone, together (cf. Smith 2004:890). In a similar regard: as people live together and with one another, so should they believe, think and talk and as they believe, think and talk, so should they pray. Prayer affects belief, which affects being church, while belief affects prayer and being church, furthermore while being church affects prayer and belief. For these reasons the term interrelationship, which accentuates the to and fro between lex orandi, lex credendi and lex (con)vivendi, is preferred to the term 'relationship'. (p. 1)

Thus, one of the research aims is to determine if people perceive that they can connect with God and fellow worshippers through prayer, within their diverse, cultural context(s). In other words, looking at the interrelationships described in the excerpt above, can or do people feel connected across their various cultures: as they live (together), so do they pray? In researching and developing a suggested theory for praxis, approaches from two different fields are explored in an interdisciplinary manner. As this was primarily concerned with the worship service it was necessary to draw on theories from Liturgical Studies including Ritual Studies.

\section{The liturgical approach}

Consider the following excerpt as a relevant, and concise, introduction in discussing the liturgical approach that was adopted when researching prayer, as worship, and culture (Barnard et al. 2014):

To pray is to accept that you can understand that your life only as an existence in relation with others and eventually with the triune God of Israel. To pray is thus a very culture-critical act. The aweinspiring godhead that is revered in worship, praying and songs is the one who promised to come, and in whom the worshippers participate in expectation but who also breaks down their autonomy and brings them into a heteronomous relation with their fellow Christians and foremost with himself. (p. 362)

This excerpt (Scott 2018) references:

\begin{abstract}
... three critical aspects of prayer in the worship service: one being the connection between the individual and God (lex orandi); secondly the relationship between individuals in the worship service being one congregation (lex (con)vivendi) and thirdly the relations between the congregation, as a single entity, and God (lex credendi). (p. 29)
\end{abstract}

These relationships and/or connections are affected equally by the encounters between culture and liturgy. There are several praxis theories on how culture(s) of worshippers and liturgical tradition(s) of the church(es) should engage with one another (cf. Chupungco 1992; Lutheran World Federation 1996:1, 1998; Wepener 2009 as immediate examples), with liturgical inculturation being the preferred approach in a postapartheid, multicultural South African setting. Liturgical inculturation can be defined as '... a continuous process of critical-reciprocal interaction between cult (liturgy) and culture so that a totally new entity comes into being, namely an inculturated liturgy' (Wepener 2009:42). 
Before entering into a discussion on why liturgical inculturation is the preferred approach, the following romantic ideal (Muchimba 2007) should be shared:

I am strongly convinced that if an indigenous group had only a Bible, they would practice their worship in a manner that would be relevant to their culture and within a biblical framework. (p. 6)

Unfortunately, this ideal is unrealistic as a result of accompanying worship traditions. Thus, 'their culture' and the already long withstanding liturgical tradition(s) should interact, thereby creating a new entity that is relevant to all involved. Muchimba is not alone when using the term 'relevant'. Senn (1983:38) suggests that: 'every generation of Christians has been concerned that its worship be relevant, at least to them'. It is understood that culture describes 'the complex aspects that culminate to determine someone's context and the way in which one experiences the worship service' (Scott 2018:28). If one's culture (as they live) determines their context (so they believe), then this frame of reference will influence the way in which one experiences liturgical tradition (so we pray/worship). Therefore, a space is created where culture and tradition interact - which has already been observed by the Lutheran World Federation (1996:1): 'The reality that Christian worship is always celebrated in a given local cultural setting draws our attention to the dynamics between worship and the world's many local cultures'. As mentioned previously, there are a number of ways in which such an interaction can happen. Four of which are suggested by the Nairobi Statement on Worship and Culture (Lutheran World Federation 1996:1). Each of these four suggestions are briefly explained in the Nairobi Statement: 'Transcultural' refers to liturgical substance being 'beyond culture'; while 'contextual' refers to variations according to the 'local situation'; 'counter-cultural' is to challenge that which is 'contrary to the Gospel in a given culture'; and lastly 'crosscultural' makes it possible to share worship between local cultures (Lutheran World Federation 1996:1).

While each of these acknowledges the presence, so to speak, of culture not all of the suggestions are inclusive of culture. For this reason, liturgical inculturation is chosen as the appropriate approach, especially in the South African postapartheid context where culture can be of severe importance to an individual and where one's heritage is intended to be celebrated. As mentioned previously, liturgical inculturation involves critical-reciprocal interactions between liturgy and culture. Thus, each is inclusive of the other as illustrated by Chupungco's (1992:32) use of a candle where one end is culture and the other tradition - each should burn and therefore meet. By meeting with one another, a space is created where culture and tradition can embrace and/or critically reject elements of the other (Scott 2018:192; Wepener 2009:39).

When considering the components of both culture and worship, it should be highlighted that culture is that which makes people unique but also what binds them. In other words, one's culture - insofar as the 'complex aspects that culminate to determine someone's context' (Scott 2018:28) creates a space in the worship service where one is exclusive, while ideally being inclusive also. This tension is something that is best explained by drawing on theories from the field of Systematic Theological Ecclesiology.

\section{The ecclesiological approach}

An article by Denise Ackermann (1998) is helpful in introducing the idea of inclusivity and exclusivity. Although it is dated, she paints an accurate picture of the South African context as a result of apartheid and not being able to accept 'the other' simply because of difference (Ackermann 1998:13-14). For the purpose of this article and for conveying the concepts used in the research project, this one sentence provides a firm starting point for this subsection, as well as a summary of the tension mentioned above: "To speak of the other is to speak of the nature of the church, the one body of many parts, challenged to unity in Jesus Christ' (Ackermann 1998:16).

Before describing the use of Systematic Theology Ecclesiological theories, it is necessary to explain the importance of developing such an interdisciplinary approach. Tom Long (2001:30), a practical theologian, writes: '... we human beings hunger for both God and community, or to put it more precisely, we hunger for God in community'. This points back to liturgical inculturation, in the sense that 'God in community' implies a liturgy that would be inculturated for such a hunger to be fulfilled. The implication is that to experience community and/ or God in community there would be a certain level of cultural cohesion. In other words, to fulfil the said hunger satisfactorily one would need to feel inclusive of the community - part of the body of Christ so to speak - and therefore worship with a community instead of in and/or amongst a community. It was when considering the dynamics suggested by the praxis theory of liturgical inculturation that Systematic Theological Ecclesiology theories on inclusivity and exclusivity, unity and diversity began being considered, while using prayer as a liturgical tool. The research problem is concerned with how the liturgical form and content of prayer impacts the ways in which people connect with God and other people in a pluralistic, postapartheid South Africa. Essentially, it is the concern over connectedness with God and/or other people that prompted the exploration of theories from Systematic Theology Ecclesiology.

\section{Ecclesiology}

Ecclesiology is the systematic study of the church (Mannion \& Mudge 2010), an acceptable definition of 'church' should first be given in order to provide a point of departure. Consider the following excerpt as such a definition:

[...] the visible community in which Christians come together for worship, prayer, communal sharing, instruction, reflection and mission ... The church can thus be viewed as one social institution among many, but also as a shared form of life shaped by profound theological self-understandings. (cf. p. 3)

It is important to mention certain aspects of the above excerpt in describing the appropriate use of ecclesiological theories 
in an interdisciplinary manner. Firstly, emphasis should be placed on the words 'visible community'; secondly on 'come together for worship'; and thirdly on 'one social institution'. The reason for placing emphasis on the term 'visible' is to reinforce that the church, as a community, is something that should be happening and not an ideal that is discussed in theory. As mentioned in the above with regard to 'God in community' (Long 2001:30), there is an element of cohesion between cultures, by focussing on the aspect of ' ... Christians come together for worship, prayer ...' the aim is to emphasise the coming together of people - thus implying social and cultural cohesion. Lastly, emphasising 'one social institution' presupposes a similar sense of belonging that one would experience as a member of a club or society.

\section{The tension between ' $\mathrm{l}$ ' and 'we'}

From the definition provided in the excerpt above, nuances of the tension(s) between inclusivity and exclusivity, unity and diversity as well as identity and otherness can be noticed. It is understood that this tension is needed within the worship service, ${ }^{3}$ as it feeds the two 'hungers' mentioned by Long (2001:30). Throughout her article, Ackermann (1998) refers to the ' $\mathrm{I}$ ' and 'we', making comparisons between the two factions - so to speak. Without yet exploring the tension between identity and otherness, instead focussing on inclusivity and exclusivity consider the concept of ubuntu. Colloquially translated the term ubuntu is understood to mean 'I am because we are'. By making such a statement the ' $\mathrm{I}$ ' is acknowledging itself as exclusive while understanding it is inclusive in the 'we' (Scott 2018:174-175).

The following quotation is an initial and strong indication of the tension that exists between inclusivity and exclusivity: 'If a person was not part of a community of God's people "in Christ," that individual would hardly be "Christian"!' (Thiselton 2015:311). Thus, in this case, reverting to the concept of ubuntu, the 'I' (Christian) can hardly be without the 'we' (community of God's people). It may be harsh to suggest that if one is not part of a community of God's people then one can hardly be Christian, especially when one does not feel inclusive in the said community owing to a lack of inculturation. It is from such statements that it seems imperative for an interdisciplinary approach to be taken, as a problem has been presented: To be Christian, one needs to be a part of a community of God's people; however, there is a situation where one experiences exclusion and therefore defines oneself as not part of the community. There is more than one cause for such an experience; Bosman and Müller (2009) from the field of Pastoral Care provide an example of a probable cause:

The fact that current liturgical renewal is not based on sound theological reflection, is cause for concern. A narrative approach to liturgy is therefore proposed, which would allow a better connection between the cultural story on the one hand, and the story of the gospel and the liturgical tradition on the other. (p. 1)
Albeit by taking a narrative approach, their concern is similar in essence to scholars of Liturgical Studies, who examine the relationship(s) between culture and liturgy. Bosman and Müller's concern is also over connectedness, which could also be seen as inclusivity. Contradictory to the above - and as mentioned earlier in this subsection - there should be a tension that is created by inclusivity and exclusivity within the church (Scott 2018:174; Volf 1996:44-45). The difference between the created tension and feeling excluded from the worship service is simply that exclusion is not necessarily one's choice but possibly because of a lack of, for example, inculturation. The benefit of adding this dynamic approach to liturgical inculturation will be highlighted when sharing the findings in a conclusion. To describe the necessary tension that is created between inclusivity and exclusivity, consider the excerpt below (Scott 2018):

By stating that 'I am because we are' the 'I' is declaring itself as exclusive, whilst also realising its inclusivity within the 'we'. In a similar manner the hypothetical believer becomes, inclusively, connected with other believers and God by joining in prayer [...] (cf. Van Deusen Hunsinger 2009:365, 366). However, said believer could remain exclusive by praying '... in honest, vulnerable expression of our own heart's longing'. (Van Deusen Hunsinger 2009:366). In the event that one believer's expressions of his/her heart's longing are different to those of other believers, then said believer becomes exclusive within the worship service. (p. 175)

Similarly, in principle to Bosman and Müller (cf. 2009), this article is concerned about how the relationship(s) between liturgical tradition and culture affect one's sense of inclusivity, not forgetting one's exclusivity, in a community of God's people. The aim of this article, however, is to address a concern over being church in a multicultural postapartheid South Africa. This is achieved by combining theories from the fields of Liturgical Studies and Systematic Theological Ecclesiology to build on the concept of liturgical inculturation, which aided in developing a theory for praxis for a pluralistic setting.

\section{Inclusivity, exclusivity and the body of Christ}

Bouteneff (cf. 2009:353) suggests, 'if the church is the body of Christ, and Christ is its head, that certainly means that the church is nothing without Christ'. Firstly, this provides a different perspective to Thiselton (2015:311), who describes the inclusion of a person in a community of God's people. Bouteneff is referring to the connection between the church and Christ, while Thiselton is referring more to the connection of an individual to a community. Secondly, by combining both Thiselton and Bouteneff's concerns, what is visible is Long's summation that '... we human beings hunger for both God and community, or to put it more precisely, we hunger for God in community' (cf. 2001:30). It is important to mention that in all cases, the singular forms are used for body and community. Thus, it is implicit that as a church there should be only one such community or body.

By using the Pauline concept of the body of Christ, scholars such as Thiselton (2015:314) and Bouteneff (2009:353) are describing inclusivity. A body is made up of many individual 
parts that function harmoniously and - in certain circumstances - rely on one another. For example, the heart requires the lungs to function to receive oxygen that is then pumped through the body. The body cannot have parts that are in conflict; for example, walking is successfully achieved only by both legs cooperating with one another. The emphasis is that the concept illustrates that inclusivity should be permanent, in the sense that the parts of the body are inseparable. Volf (cf. 1996) begins explaining the sense of belonging that should come with inclusivity, similarly to the concept above, as follows:

Much like Jews and Muslims, Christians can never be first of all Asians or Americans, Croatians, Russians, or Tutsis, and then Christians. At the very core of Christian identity lies an allencompassing change of loyalty, from a given culture with its gods to the God of all cultures. (p. 40)

The relevance of this is that Volf acknowledges the tension between inclusivity and exclusivity, in a postapartheid urban setting such an acknowledgement is crucial. While all parts of the body of Christ are Christian and thereby inclusive, they are different parts - as in 'arms' and 'legs' for example - who come from different cultures and are exclusive in that. It is important to mention that the worshippers that Volf is referring to are both Christian but also 'Asians or Americans ...' or Africans (cf. 1996:40). Thus, he acknowledges, in terms of liturgical inculturation, that these worshippers bring culture with them to withstand tradition. Unlike, the 'counter-cultural' approach of the Nairobi Statement (Lutheran World Federation 1996:1), Volf's approach is simply that individuals should pledge their allegiance to the God of all cultures, thus belonging to and being inclusive in the body of Christ then secondly practising exclusivity by not 'losing' one's culture. In achieving this, a sense of belonging can be experienced with 'the other' while not denying one's identity (cf. Ackermann 1998).

In light of taking an interdisciplinary approach, the above theories can be integrated to form a theory for praxis which aids making worship 'relevant' so that worshippers can fulfil their hunger(s) for God and community. ${ }^{4}$ In the conclusion below, the results of integrating theories from the fields of Liturgical Studies and Systematic Theological Ecclesiology will be presented to share the 'new knowledge' that was formed by taking this interdisciplinary approach.

\section{A sense of belonging}

Currently, in South Africa, there is a trend that suggests all voices should be heard especially regarding social injustices such as discrimination in all its forms (cf. Buthelezi 2018; Fisher 2017; Scott 2018:191; Wepener 2015). These voices, one and all, speak for equality, their rights and the fulfilment of promises made to them. ${ }^{5}$ Normatively speaking, liturgy should be considered as 'the expression of all the people of God' 4. The term 'relevant' is put in inverted commas as it is meant to portray what is
insinuated by Muchimba (2007:6) and Senn (cf. 1983:38). Tom Long (cf. 2001:30), a
practical theologian, writes: '... we human beings hunger for both God and community, or to put it more precisely, we hunger for God in community'.

5.A recent example of this is the public hearings on land expropriation that were held around South Africa in 2018.
(Ramshaw 1996:10), thereby enacting Smit's aphorism of: 'as we worship (or pray), so we believe, so we live (together)' ${ }^{6}$

Whether focussing on the term 'all' or emphasising the 'we', the point being conveyed is one of unity and inclusivity, in other words a liturgy that is inclusive and free of the distinctions of 'otherness' (Ramshaw 1996:11; Scott 2018:191). Additionally, as proposed by the Lutheran World Federation (1996:3), this inclusive liturgy could transform cultural patterns that 'idolise the self or the local group at the expense of a wider humanity' similarly to Volf's notion that 'At the very core of Christian identity lies an all-encompassing change of loyalty, from a given culture with its gods to the God of all cultures' (cf. Volf 1996:40). At this point, it is necessary to remember that where there is inclusivity - in the form of the Pauline body of Christ - there should be exclusivity, in the sense that a body is one whole of many different parts.

Thus, in light of all that has been described and discussed above, a theory for praxis has been developed that integrates theories of liturgical inculturation from the field of Liturgical Studies, inclusivity and exclusivity from the field of Systematic Theological Ecclesiology, as well as the concept of koinonia. Due to the tensional aspects of inclusivity and exclusivity, once integrated with the praxis theory of liturgical inculturation, a theory for praxis that is twofold was developed. This theory for praxis consists of two main foci: (1) exclusive connectedness and (2) inclusive connectedness (Scott 2018:195-201).

The latter focus, inclusive connectedness, is concerned mainly with that which has been described throughout the article with regard to inclusion and the primary function of liturgical inculturation: 'the process whereby the worship service and all its connected elements and practices are given alternative forms that correspond with the cultures and traditions of the church' (Chupungco 1982:185). The aim of taking such an interdisciplinary approach was in the expectation of creating new knowledge, be it in the form of a theory for praxis, that is beneficial. In doing so, the following is proposed in a response to Long (2001:30), who explains that there is a profound human need: a 'hunger for God in community' and later suggests that: 'If we listen carefully, we can hear this hunger for God in community in the cries of our culture':

In aiding unity and inclusivity, the process of liturgical inculturation can make use of such aspects as ritualisation. If awareness of the other discloses social and ethical expectation and demands, it can be speculated that worshippers expect inclusivity through invitation, mutual understanding and relevant, or common, participation in liturgical rituals for example. (Scott 2018:200)

Immink (2016:7) states, 'Prayer not only activates the human self but also evokes God's presence'; this is in describing the level of self-involvement that a supplicant enacts through prayer. It should be mentioned that the above quote is referring to 6.Dirk Smit (cf. 2004): Lex orandi, lexcredendi, lex(con)vivendi, which is loosely translated as 'as we pray, so we believe, so we live (together)'. 
supplicatory prayer, regardless of if it alluds to situations where an individual-involved in prayer with a congregation - connects exclusively with God. This is, as referred to above, exclusive connectedness which corresponds with Long's other profound human need - a 'hunger for God' (Long 2001:30). In other words, a worshipper can connect exclusively with God through the same form of prayer as the inclusive congregation but with personalised content. In terms of the body of Christ concept, exclusive connectedness can be described as (Scott 2018):

[...] The 'right arm' whilst part of the body can function independently to the 'left arm'... whilst the whole body is driving a vehicle, similarly to the entire congregation praying simultaneously, the one arm is operating the steering wheel whilst the other arm is alternating gears by using the gear lever. It is possible in accordance with this explanation that one worshipper, albeit the one arm or the other, can pray in simultaneous form as all others, such as the whole body being in the act of driving, yet pray different content to all others. (p. 196)

When considering 'exclusive connectedness' as an additional concept within liturgical inculturation, as suggested by Wepener (2008:318), a series of questions should be asked. One such suggested question is: 'To what extent is this liturgy a relevant expression regarding the experiences and spiritualities of the celebrating people?' (Wepener 2008:318) This question is imperative to liturgical inculturation; however for the purpose of ensuring exclusive connectedness, the question can be adapted to: 'to what extent is this prayer form a relevant expression regarding the content that impacts experiences of exclusive spirituality of the celebrating persons?' (Scott 2018:197) This serves as an example of how the process of liturgical inculturation can be adjusted to include a worshipper's exclusive hunger for God while maintaining its primary focus - creating an inclusive connectedness or an inculturated liturgy. The reason this is suggested is because of the interpretation that one's exclusivity cannot be avoided, although their inclusivity, or faith, in the worship service should be paramount (Thiselton 2015:321; Volf 1996:40).

\section{Conclusion}

In the introduction section, out of concern over being church in a multicultural urban setting in postapartheid South Africa, a question was posed: 'can the church, by way of liturgy and prayer, make a meaningful contribution to cohesion in South Africa, in terms of how people connect to one another?' The previous section, entitled 'A sense of belonging', suggests that by considering one's hunger for God and one's hunger for community, the church can make a meaningful contribution to social cohesion through liturgical inculturation that embraces the creative tension between inclusivity and exclusivity as a result of the 'diversity of humanity' and 'the challenge of dealing with otherness' (Van Wyk 2014:2).

\section{Acknowledgements Competing interests}

The authors declare that they have no financial or personal relationships that may have inappropriately influenced them in writing this article.

\section{Authors' contributions}

This article is based on the PhD thesis of H.R.S. C.W. was the supervisor and T.V.W. was the co-supervisor.

\section{Funding information}

This research received no specific grant from any funding agency in the public, commercial or not-for-profit sectors.

\section{Disclaimer}

The views and opinions expressed in this article are those of the authors and do not necessarily reflect the official policy or position of any affiliated agency of the authors.

\section{References}

Ackermann, D.M., 1998, 'Becoming fully human: An ethic of relationship in difference and otherness', Journal of Theology of Southern Africa 102, 13-27.

Barnard, M., Cilliers, J. \& Wepener, C., 2014, Worship in the network culture: Liturgica Ritual Studies: Fields and methods, concepts and metaphors, Liturgiacondenda 28, Peeters, Leuven.

Bosman, L. \& Müller, J., 2009, 'n Narratiewebenaderingtot die Liturgie', Verbum et Ecclesia 30(2) Art \#179, 1-6. https://doi.org/10.4102/ve.v30i2.179

Bouteneff, P.C., 2009, 'Ecumenical ecclesiology and the language of unity', Journal of Ecumenical Studies 44(3), 352-360.

Buthelezi, M., 2018, 'Let all voices be heard by Parliament - IFP', viewed 10 January 2019, from https://www.iol.co.za/capeargus/opinion/let-all-voices-be-heard-byparliament-ifp-16425276.

Chupungco, A.J., 1982, Liturgies for the future, Wipf and Stock Publishers, Eugene, OR.

Chupungco, A.J., 1992, Liturgical inculturation: Sacramentals, religiosity, and catechesis, The Liturgical Press, Collegeville, PA.

De Klerk, J.N., 2016, 'Pilgrimage as a challenge to reformed liturgical praxis', Unpublished PhD thesis, University of Pretoria.

Fisher, R., 2017, 'Voices of ordinary people matter in a just society', viewed 10 January 2019, from https://www.iol.co.za/news/opinion/voices-of-ordinary-people-matterin-a-just-society-11049661.

Flynn, D.S., 2015, 'Aanbidding sport ensosialekohesie: 'n Ruimtelik-liturgieseperspektief', Unpublished PhD thesis, University of Pretoria.

Grimes, R.L., 2010, Beginnings in ritual studies, 3rd edn., Ritual Studies International, Waterloo, Canada.

Immink, F.G., 2016, 'The sense of God's presence in prayer', HTS Teologiese Studies/ Theological Studies 72(4), a4122. https://doi.org/10.4102/hts.v72i4.4122

Johnson, C.V., 2005, 'Researching ritual practice', Studia Liturgica 35(2), 204-220. https://doi.org/10.1177/003932070503500205

Lloyd, T., Steven, J. \& Tovey, P., 2010, Social science research methods in contemporary liturgical research: An introduction (Joint Liturgical Study 39), Hymns Ancient and Modern.

Long, T.G., 2001, Beyond the worship wars: Building vital and faithful worship, The Alban Institute, Inc, Bethesda, MD.

Lukken, G., 1999, Rituelen in overvloed, Gooi \& Sticht, Baarn.

Lutheran World Federation, 1996, Nairobi statement on worship and culture: Contemporary challenges and opportunities, Lutheran World Federation, Geneva.

Lutheran World Federation, 1998, 'Chicago statement on worship and culture: Baptism and rites of life passage', Studia Liturgica 28, 244-252.

Mannion, G. \& Mudge, L.S. (eds.), 2010, The Routledge companion to the christian church, Routledge (Routledge companion), New York.

Muchimba, F., 2007, Liberating the African soul: Comparing African and Western Christian music and worship styles, Authentic Publishing, Colorado Springs, CO.

Osmer, R.R., 2008, Practical theology: An introduction, W.B. Eerdmans, Grand Rapids, MI.

Post, P., 2015, Ritual studies, Oxford Research Encyclopaedia of Religion, viewed 18 April 2017, from http://oxfordre.com/view/10.1093/acrefore/9780199340378.001.0001/ acrefore-9780199340378-e-21.

Ramshaw, G., 1996, Liturgical language: Keeping it metaphorical, making it inclusive, The Liturgical Press, Collegeville, PA.

Scott, H.R., 2013, 'Transformation in the worship service: A ritual-liturgical exploration', MA Theology Mini-dissertation (not published), University of Pretoria.

Scott, H.R., 2018, 'Praying, believing and being church: A ritual-liturgical exploration', Unpublished PhD thesis, University of Pretoria.

Scott, H.R. \& Wepener, C.J., 2017, 'Healing as transformation and restoration: A ritual liturgical exploration', HTS Theological Studies 73(4), 1-9. https://doi.org/10.4102/ hts.v73i4.4064 
Senn, F.C., 1983, Christian worship and its cultural setting, Fortress Press, Philadelphia, PA.

Smit, D.J., 2004, 'Lex orandi, lex credendi, lex (con)vivendi? - Oriënterendeinleiding to liturgieenetiek', NederduitseGereformeerdeTeologieseTydskrif (NGTT) 45(3-4), 887-907.

Smith, K.G., 2010, 'Review of Richard Osmer, practical theology: An introduction, R.R. Osmer: Book review', Conspectus: The Journal of the South African Theological Seminary 10, 99-113.

Thiselton, A.C., 2015, Systematic theology, W.B. Eerdmans, Grand Rapids, MI.

VandeCreek, L., Janus, M.-D., Pennebaker, J.W. \& Binau, B., 2002, 'Praying about difficult experiences as self-disclosure to God', The International Journal for the Psychology of Religion 12(1), 29-39. https://doi.org/10.1207/S15327582 IJPR1201_04

Van Deusen Hunsinger, D., 2009, 'Practicing Koinōnia', Theology Today 66(3), 346-367. https://doi.org/10.1177/004057360906600306

Van Wyk, T., 2014, 'Church as heterotopia: Original research', HTS: Theological Studies 70(1), 1-7. https://doi.org/10.4102/hts.v70i1.2684
Volf, M., 1996, Exclusion and embrace: A theological exploration of identity, otherness, and reconciliation, Abingdon Press, Nashville, TN.

Wepener, C., 2005, 'Researching rituals: On the use of participatory action research in liturgical studies', Practical Theology in South Africa 20(1), 109-127.

Wepener, C., 2006, 'The object and aim of multi-disciplinary liturgical research', Scriptura: International Journal of Bible, Religion and Theology in Southern Africa 93(1), 384-397.

Wepener, C., 2008, 'Liturgy on the edge of tradition', Practical Theology in South Africa 23(2), 313-335.

Wepener, C., 2009, From fast to feast: A ritual-liturgical exploration of reconciliation in South African cultural contexts, Peeters, Dudley.

Wepener, C., 2015, “"Bliksem!"/damn it! A ritual-liturgical appreciation of a deadly sin for an angry nation', Verbum et Ecclesia 36(3), Art. \#1422, 1-8. https://doi. org/10.4102/ve.v36i3.1422

Wepener, C. \& Barnard, M., 2010, 'Entering the field: Initiating liturgical research in an AIC', Acta Theologica 30(2), 192-210.

Zizioulas, J.D., 2006, Communion and otherness: Further studies in personhood and the church, T\&T Clark, London. 